\title{
Classroom Action Research-Based Lesson Study in Determining The Formula of Circle Area
}

\author{
Sunata \\ Pasundan University, Faculty of Teacher Education and Science, Bandung, Indonesia \\ sunata@unpas.ac.id
}

\begin{abstract}
The purpose of this study investigated and understand impact of classroom action research- based lesson study in determining the formula of circle area. This kind a classroom action research in the subject of money and bank in order to participate in solving problems related materials. The Subject of this study is Grade 6 student in academic year 2017/2018. The implementation classroom action research conducted in two cycles comprising Planning, Implementation, observing, and reflection stages. The result of this study that classroom action research-based lesson study in determining the formula of circle area has been well implemented including the completeness of the learning tools and preparing the Lesson Plans before teaching on each teaching material. Based on the results of the implementation of classroom action research-based lesson study can be concluded that classroom action research-based lesson study can improve student achievement.
\end{abstract}

Keywords: Classroom Action Research-based lesson study, Circle Area

\section{Preliminary}

The development of education world is influenced by many factors, including the quality of human resources. As in secondary school level education, teachers take a high responsibility in the process of teaching and learning process. To improve teacher's competency, the government has conducted several strategic steps as inservice teaching service that contains workshop of equality, technical training, workshop and others. The result of human resource development strategy through inservice teaching service is expected can be implemented in the teaching and learning process in the classroom. However, in fact, the result after those steps does not indicate a significant impact. There is a question; still, can the participants improve the quality of learning? Basically, the core mission of inservice teaching service is to improve the teacher's competency and quality, and more than that, a participant teacher can be able to apply the training points and gives some expected influences to his or her colleagues at school (Sukirman D, 2006). In fact, even certified teachers does not have any difference than those whose are not certified yet related to improvement of capability in teaching. It requires teacher's deep attitude and morals to always think how to improve it. The improvement of teacher's quality will enable students improve their quality, too.

Learning quality both in primary school and university level at least influenced by three main factors, namely; 1) Student's existence and their characteristics (raw input), 2) learning supporting instruments (instrumental input), and 3) the 
atmosphere or environment around the learning process held (environmental input). Each factor divided into several components. Raw input consists of student's characteristics; interest, talent, intelligence and maturity. Instrumental input consists of teacher's existence, objective of curriculum, textbook, learning approach and method, media, evaluation instrument, facilities and infrastructures. While environmental input includes physical environment such as buildings, location, temperature and nonphysical environment such as family and the society.

How to improve teacher's competencies to become professional teacher? Classroom Action Research-based lesson plan is expected can contribute solution since it is a teacher professional development model through collaborative and sustainable learning assessment based on collegiality principles and mutual learning to build effective learning community. This lesson study leads teachers to work collaboratively; first, to analyze learning problems, both learning materials and method. Next, teachers find out the solution and to design innovative and student-centered learning. And then, some teachers apply the method in the classroom while the remaining take role as the observers and finally, all teachers discuss it to make review and reflection. If the lesson study principles are applied in systemic and sustainable way, it will be possible to make significant result to support improvement of quality education in Indonesia.

Beside to improve teacher's professionalism, lesson study as one of academic instrument can be also attempted to improve lecturer and student college competency. It can be developed in each LPTK (institution for teacher and for teaching staff) campus as a research to analyze teaching and learning process as a study-based learning to determine innovations toward certain lesson or subject. Basically, a lesson study in LPTK is intended as a tool of student's and lecturer's improvement where in the process of teaching and learning all sides are potentially take role as an observer so that students and lecturers have the opportunity to share their learning experiences among them.

Epistemologically, the words Lesson study come from Japanese; jugyokenkyu. It can be defined as systematic process used by Japanese teachers to assess the effectiveness of teaching in order to increase learning objectives (Garfield, 2006). The intended systematic process is teacher's collaborative work to develop lesson plan and learning instruments by conducting observation, reflection, and revision of lesson plan continuously and make it as a cycle. (Lewis, 2002) states that the idea in the core of lesson study is actually simply comprehended, that is if a teacher is willing to improve a learning quality, he or she has to make collaboration with other teachers by designing, observing and making reflection toward learning process which is conducted.

While Classroom Action Research has a purpose to improve the quality of teachers in relation with upgrading learning materials, input and output, process and objectives. It is also meant to grow new culture for those lecturers so that they are motivated to conduct researches and push them to be more pro-active in finding solutions concerning learning problems. 
Increasing the collaboration between Students College and lecturers is supposed to be able to overcome learning problems. The characteristics of Classroom Action Research; inquiry, reflective and collaborative. The developing of these characteristics can be done through the following steps; (1) problems focus fixation, (2) action planning, (3) actions, (4) observation, (5) reflection, (6) following-up plans.

On the other words, Classroom Action Research can be meant as recycled controlled action (in a cycle) to directly overcome the real and specific problems found in learning process. From this explanation it can be concluded that Classroom Action Research has characteristics as follow; (1) action existence in improving learning quality (inside and outside of class, (2) the selected actions are specified and based on the problems faced, (3) the focus on the process and the action results, (4) not for generalization and no sampling, (5) data collection; interview, observation, questionnaire, test, (6) all things are done in a cycle including: planning, action, observation, and reflection.

\subsection{Classroom Action Research-based Lesson Study}

Lesson Study as a research includes three main steps; planning step, implementing step, and reflection step. The following scheme can be a further explanation:

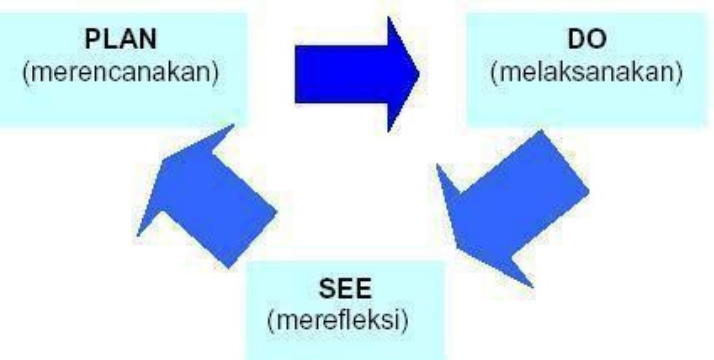

Picture 1. The activities in Lesson Study

An implementation of Lesson Study as was conducted by IMSTEP-JICA in Indonesia, (Saito et al., 2006) in which it introduces practice-oriented lesson study, at that opportunity, lesson study was implemented in three phases;

1. To plan learning activity with academic dignity toward some topics and used learning tools, this activity is called as plan phase.

Stage 1:

Planning

Problem identification (subject matter relevant to class and lesson schedule, student characteristics and classroom atmosphere, learning approaches / methods, media, props, and assessment) and alternative solutions.

1. Preparation of Research Theme

2. Preparation of learning tools consisting of:

3. Lesson Plans (RPP)

4. Worksheet (LKS)

5. Media and Display Tools

6. Instrument assessment process and learning outcomes. 
7. Observation

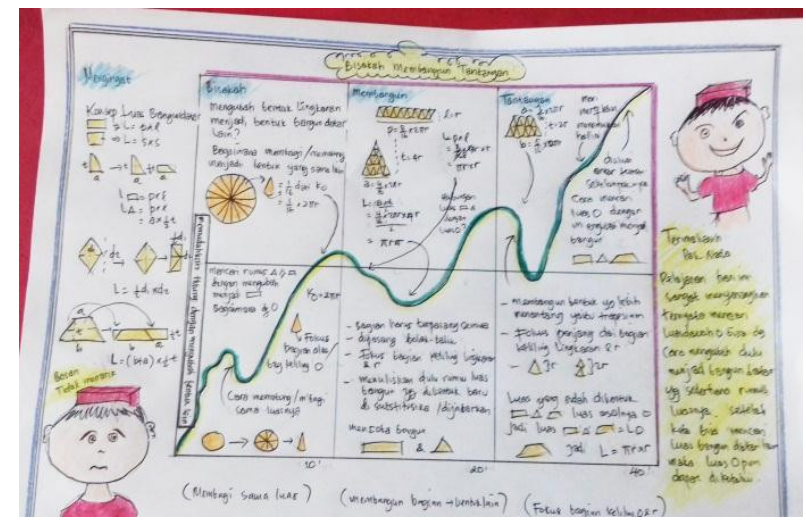

Picture 2. Lesson Plan

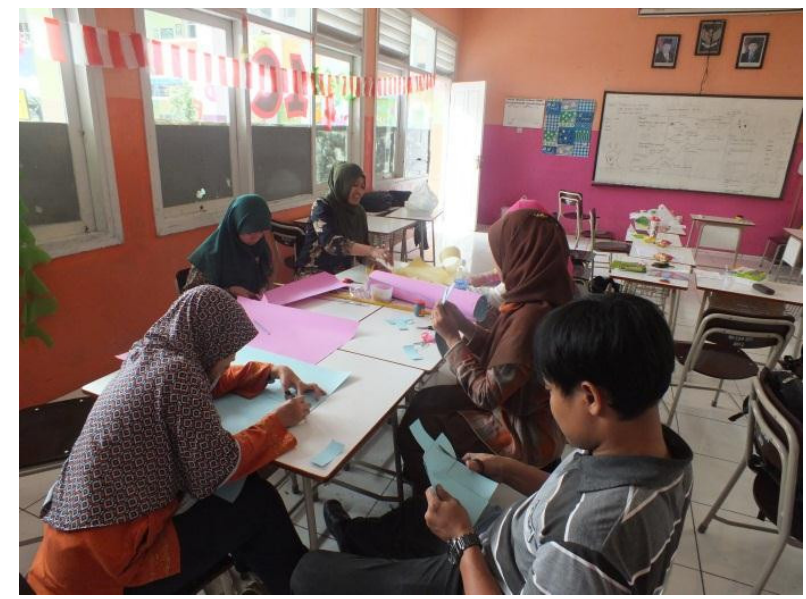

Picture 3. Lesson Design

\section{To do learning based on lesson plan and provided tools, and by asking colleagues to observe. This phase is called as do phase.}

Stage 2: Implementation and observation stage in observing students, observers are advised:

1. Record students' comments or discussions and write down the student's name or position.

2. Make notes about situations when students cooperate or choose not to cooperate.

3. Looking for examples of the construction process of understanding through discussion and learning activities undertaken by students.

4. Record variations of individual problem solving methods by individual students or groups including incorrect resolution strategies.

5. Do students use their original knowledge or prior knowledge to understand new concepts learned?

6. Is the student's way of thinking facilitated and motivated by the questions asked by the teacher?

7. Are student ideas rewarded and associated with the material being studied?

8. Is the final conclusion based on student opinion?

9. Is the conclusion put forward according to the learning objectives? 
10. Is there a strengthening of the students' competencies?

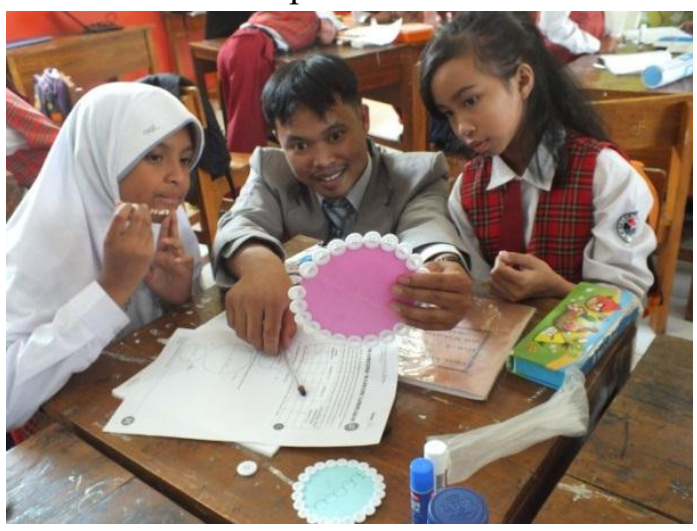

Picture 4. Explanation from the teacher

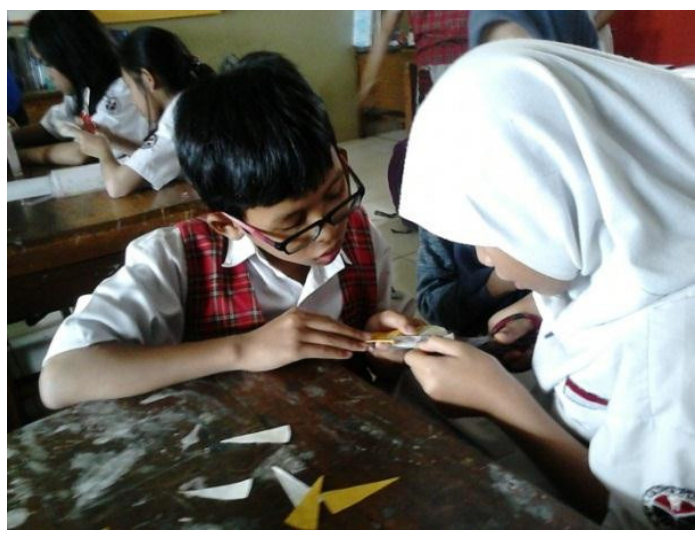

Picture 5. Collaboration betwen students

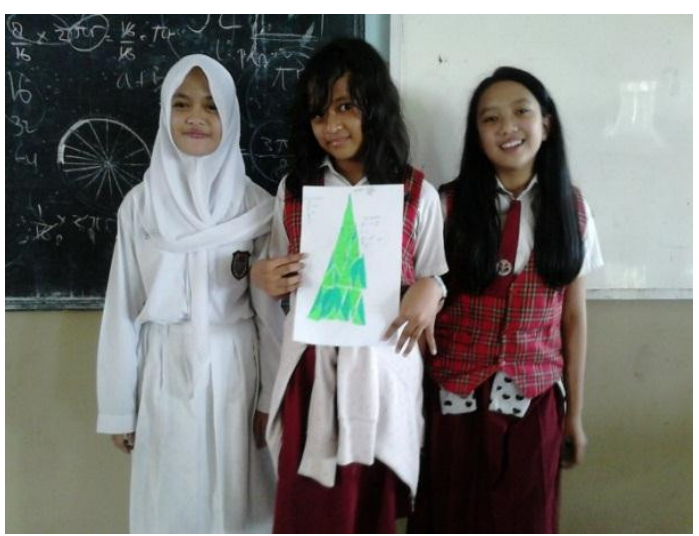

Picture 5. Presentation of work result

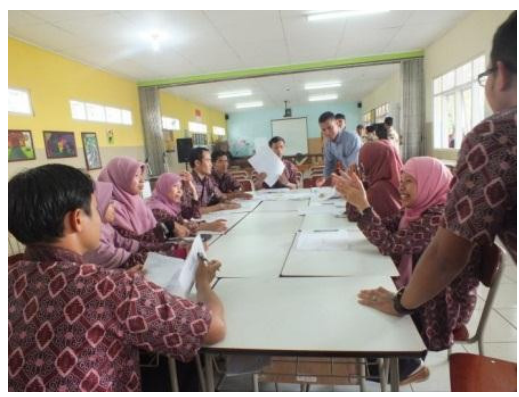

Picture 6. Reflection and discussion with observers 


\subsection{Do reflection through sharing and discussion with observers, it is called see phase}

In research in action phase, there is a monitoring activity to acquire a description and the causality the effect of the implementation. In this phase, the data resulted from monitoring is used to make decision about how far correction should be done related to action planning on each cycle. Therefore, the decision made is at formative evaluation level.

1. Teachers who carry out the learning activities express his impressions during the activities took place about himself and students.

2. Observers (other teachers and experts) presented the results of their observational data analysis, particularly those involving student activities during the learning activities that were accompanied by video playback of the recording of learning activities.

3. The teacher who performed the implementation provided feedback on the comments of the observers.

4. Revision of learning tools.

5. Understanding according to English-Indonesian Dictionary is a translation of comprehension. In the big Indonesian dictionary, understand has the meaning to understand right, know right. (sudjana, 1996) suggests understanding of an operational nature of understanding is defined as seeing a relationship, understanding is defined as a tool using facts, and understanding is interpreted as seeing the use of something productively

\subsection{Kind of Classroom Action Research-Based Lesson Study}

Lesson Study as one of Classroom Action Research can be applied in several forms. According to (Kemmis \& McTaggart, 2007), there are three forms of Classroom Action Research, Classroom Action Research which is applied individually, collaboratively, and in institutionally.

Lesson Study as Classroom Action Research applied individually Lesson Study as Classroom Action Research applied individually, where a teacher or lecturer do it take a role as researcher and practitioner at the same time. As a researcher, a teacher or lecturer must be able to work as in his research line. That is the action should be intended to improve learning quality by applying clear and responsible steps. It means that he or she can guarantee the validity of data collected so that it directly support the research objectivity, moreover, it has sufficient accuracy of interpretation and accuracy in conclusion. For these reasons, this kind of Classroom Action Research must be supported by critical friends.

A right critical friend is very useful to assist researcher in doing reflection. Besides that, critical friend can also take role as another observer when the real researcher conducts learning practice as practitioner. If the real researcher conduct is without any critical friend, it will be possible for other sides to question the research objectivity. Critical friend is selected based on the skill or needs. Therefore, critical friend may change as it has functions and meant to support the successes of lesson study itself. If the real researcher is an experienced or senior teacher or lecturer, and 
they are familiar with it, and they usually supported with adequate facilities such as recording instrument in audio visual instrument, so it can involve critical friend to criticize the results after analyzing the recording data. Therefore, critical friend is only involved in reflection phase and at the same time to criticize the application of lesson study. Even, a critical friend can adopt it if the results are positive. Otherwise, for beginners, it enables them to involve critical friend on each phase of lesson study, starting from problems selection, planning, action, reflection, up to reporting phase.

\subsection{Lesson Study as Classroom Action Research Applied Collaboratively}

Classroom Action Research in group form will involve a group of teachers or lecturers and it will place part of them as researcher and the remaining as practitioners. The collaboration can also be done between the teachers and the lecturers themselves. in collaboration between a teacher and a lecturer, the problems are explored in the field together as the lecturer take a role as an initiator to offer the problem solving based on the are selected. In this case, the research validity can be more accurate because the researcher and the practitioner exist.

\section{Lesson Study as Classroom Action Research Applied Institutionally}

Lesson Study as Classroom Action Research applied individually or collaboratively has limited scope or it just focuses on small area topic. For example, the research will only focus on the relation between the learning process and the desired results. Lesson Study as Classroom Action Research applied institutionally has a larger research scope and it is intended to make correction to the institution itself. So, in one research it can be determined several area topics. In this kind of lesson study, it involves collaboration and can be built largely with the participants from many sides. For school, they can involve students, teachers, staffs, parents, principals, related department, and college lecturers. For a college campus, it can involve Students College, staffs, the stakeholders, and other sides.

The main aim of Classroom Action Research institutionally is to improve the institution itself. Therefore, it is possible to make researcher groups according to relevant area topics. As stated by (Kemmis \& McTaggart, 2007) that in this kind of Classroom Action Research, small groups can conduct experiment to test several innovations for problems faced.

\section{Models of Classroom Action Research-based Lesson Study}

\subsection{Model of Kemmis and McTaggart (2007)}

Steps in this kind of Classroom Action Research are applied cycle-to-cycle. First cycle is initiated with (a) early reflection to hold investigations in order to set area topic (thematic concern) which will be studied, and the will follow; (b) whole planning, (c) the implementation of action and observation, and (d) reflection. Next cycle is begun with (1) advanced-planning phase as revision form for previous planning by 
utilizing reflection results, (2) advanced action and observation, and (3) advancedreflection.

\subsection{Model of McKernan (Hopkins, 1993)}

This kind of Classroom Action Research is held by cycle-to-cycle and started with an early cycle; (a) determining problems, (b) need assessment to explore root of problems, (c) formulating hypothesis, (d) implementing the actions, (e) evaluation, and (f) decision making. After the early cycle, the next cycle is begun with (1) re-determining problems, (2) need assessment to re-explore the roots of problem, (3) formulating new hypothesis, (4) implementing the plan, (5) evaluation, (6) decision making.

\subsection{Model of Ebbut (Hopkins, 1993; McNiff, 1992)}

This kind of Classroom Action Research is conducted in cycle to cycle. The first cycle begins with ; (a) determining the general ideas, (b) doing investigation, (c) setting whole plan, (d) executing first action, (e) monitoring and doing further investigation, the results from point (e) is utilized to (1) revising arranged whole plan, (2) fixing the general ideas, (3) to reach the next phase. According to Elliott (Hopkins, 1993; McNiff, 1992) the Classroom Action Research is held in cycle-to-cycle. First cycle begins with: (1) recognizing early ideas, (2) doing investigation by looking for the fact and then analyze it, (3) setting general plan which consists of several phases, (4) doing first phase action, (5) monitoring the first action phase and analyze the effect, (6) doing an investigation to scan failure or error and the effects. The results of this investigation are used to revise general ideas with all action phases inside it, and then carrying out the revised actions, monitoring the action phases and eventually, re- investigating it as the input for the next cycle.

\section{Research Method}

This type of research is a classroom action research based on Lesson Study. This research using qualitative descriptive approach. Classroom action research defined as one of the problem-solving strategies that utilize concrete actions and capacity building processes in detecting and resolving problems. This research was conducted in two cycles through four stages: action plan, implement, observe, and reflection. The subjects of this study were students of Grade 6 SD Labschool UPI in the subject of circle area. The data collection tool uses, observation sheets, field note sheets, test questions, questionnaires, and documentation. Data collected by using test questions, interviews, observation sheet. Data analysis can be done in the following way: (1) Classify data by grouping, selecting, focusing, and simplifying data according to its type from the beginning of data collection to the preparation of reports; (2) Presentation of data that has been selected and will be presented in the form of simple information. The information in question is a description of the learning process and the results obtained from the combination of observation and interview data; (3) Conclusion. From the exposure of the data will be obtained conclusion in the 
form of a short sentence but has a broad meaning. From the results of the conclusions are used to test the truth and match the meaning of the data obtained in the field.

Assessment of student achievement obtained from the cognitive test score at each end of the cycle. To know the improvement of student learning outcomes seen from the completeness of student learning outcomes in each cycle consisting of individual completeness and classical completeness. Students expressed (individually) in learning when the final grade reaches $\geq 75$. On classical completeness expressed when the value of classical completeness reaches $85 \%$.

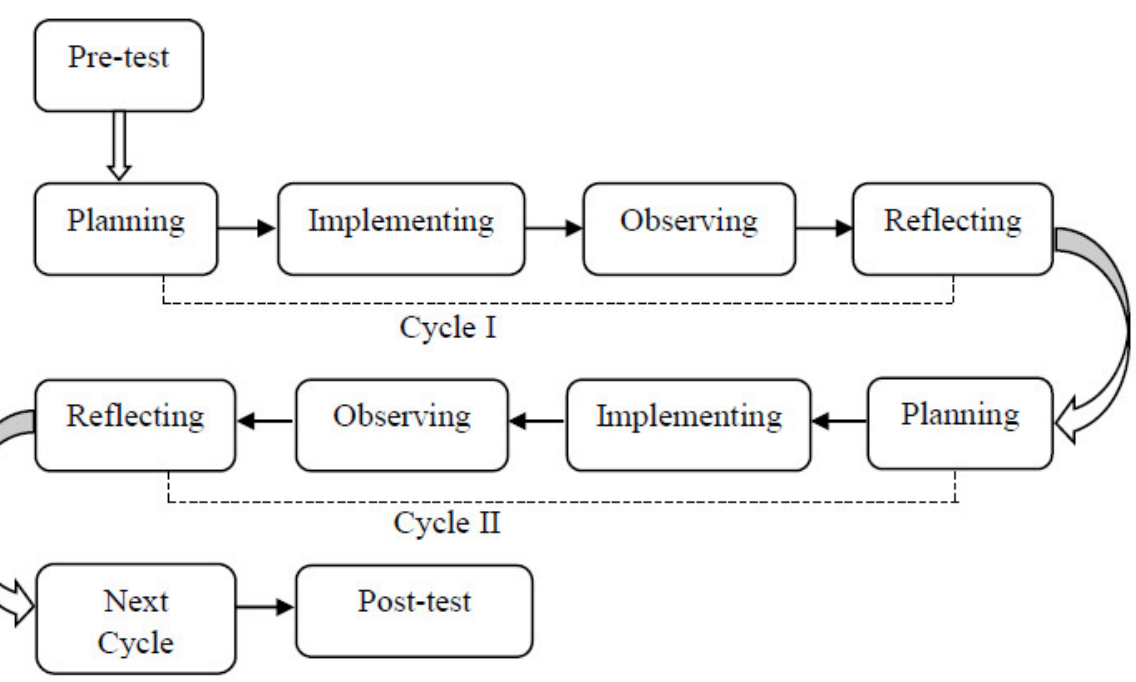

Picture 7. Research Design

\section{Result And Discussion}

\subsection{Implementation Classroom Action Research-Based Lesson Study In Determining The}

\section{Formula Of Circle Area}

The Implementation Classroom Action Research-Based Lesson Study In Determining The Formula Of Circle Area conducted by four cycles. The learning activities stages consisted of: identify topic, develop and present the report, analyse, and evaluate the inquiry Learning. The learning process through lesson study presented in this table.

Table 1.Schedule implimentation through lesson study

\begin{tabular}{|c|c|c|c|c|c|}
\hline No & Cycles & Stage Plan & Do & See & Learning material \\
\hline 1. & I & $\begin{array}{l}\text { Plan I, Januari 8, } \\
2018\end{array}$ & Do I, Januari 9, 2018 & Do I. Januari 9, 2018 & Phi \\
\hline 2. & I & $\begin{array}{l}\text { Plan II, Januari 15, } \\
2018\end{array}$ & Do I, Januari 16,2018 & Do I, Januari 16,2018 & Perimeter of circle \\
\hline 3. & II & $\begin{array}{l}\text { Plan III, Januari 22, } \\
2018\end{array}$ & Do I, Januari 23, 2018 & Do I. Januari 23, 2018 & Circle Area \\
\hline 4. & II & $\begin{array}{l}\text { Plan IV, Januari 29, } \\
2018\end{array}$ & Do I, Januari 30, 2018 & Do I, Januari 30,2018 & Circle Area \\
\hline
\end{tabular}


The implementation of lesson study started from the plan stage of discussing the lesson plan together with observed for advice and feedback. In the plan stage follow lesson plan material about circle area, learning sheet, instrument for Lesson Study, and teaching materials. The prepared format includes the observation format and order of implementation Lesson study. This format is structured to document all lesson study activities so that accurate reflection can be done.

In addition, lesson study team members also plan and develop complete learning tools and instruments for the purpose of the implementation phase (plan), namely the preparation of lesson plans, material handouts, Student Activity Sheets, observation sheet of teacher activities and students in Inquiry learning.

In the next stage is implementation phase (do) by teacher model implementing lesson plan before. The preliminary in this stages suggest a teacher model giving perception, motivation, and explain the learning model. The implementation of learning is divided into five activities namely the initial activity core activities consisting of stages of student orientation to the problem; organize students to learn; guide individual and group investigation; develop and present the work; and analyze and evaluate the learning process; and the final activities. This is in accordance with the lesson plan with the inquiry learning model, with the help of three members of the lesson study team will observe activity undertaken by teachers and students in the learning process.

At the reflection (See) stage, reflection on learning outcomes is conducted in accordance with the implementation of lesson study activities and analyzing the overall learning that is done. At this stage jointly implemented by all the components that are present both groups of subject teachers and observers, because the results of discussion and analysis can be used as input to improve or revise the next lesson.

Based on the observation result, the learning process did not found the basic problem among the implementation. Challenges in implementation of lesson study, especially for grade Junior High School, the students were still less active in group discussions and class discussions. Students are still less familiar with group learning especially with groups that are not in accordance with the wishes of students. Students are still inclined to work individually and ask for immediate difficulties to the teacher instead of being discussed first with group members. Timing of activities by teachers has not been effective, especially for discussion time and time for presentation. During the discussion, the teacher did not give the confirmation of the time given for the discussion, so the students stalled during the discussion. The teacher does not provide time settings so that there are empty times that students use to joke themselves. Students are still difficult to express the reasons for the answers given, still ashamed to ask questions, answer questions or respond.

A learning process through Lesson Study that was conducted in this study was the second experience. Through Lesson Study, we learn much from learning facts found. Lesson Study becomes a means to improve learning process and functions as a means of learning for lecturers who are involved in the process, from planning the lesson plan until implementing the planned lesson plan (Asyari, M., Mudhar, M. H. I. A., Susilo, H., 2015). 
The implementation of Cycle $\mathrm{I}$ is conducted in two meetings. Based on of the premilinary study, pre-test conducted by students at the beginning of learning (before action) obtained data as follows:

Table 2. students' score before action

\section{Pre Test}

Score

\begin{tabular}{ll}
\hline Average Score & 69,90 \\
\hline Precentage of mastery & \\
$55,7 \%$ Source : Data processed, 2018
\end{tabular}

While the post test result conducted by students after the following actions

Table 3. Post-test score after action

Post Test Score

\begin{tabular}{ll}
\hline Average Score & 86,80 \\
\hline Precentage of mastery & \\
\hline $87,30 \%$ Source : Data processed, 2018
\end{tabular}

From the above data it can be seen that the average student's post test score is 86,80 . In addition, the percentage of students' completeness in post-test cycle I is $87,30 \%$. This means that the percentage of classical completeness in cycle I is still not reached $85 \%$. To measure the achievement of learning through Classroom Action Research done with three observers.

\subsection{Comparison of Cycle I and Cycle II}

Based on the results of observation on the achievement of teacher action in applying the lesson with Classroom Action Research learning model and student achievement in learning activity during cycle I and cycle II, as well as data that has been collected and analyzed, the percentage of student achievement showed improvement. The implementation of action research activities in the application with Classroom Action Research learning model can be seen below:

Table 4. Comparison of cycle I dan cycle II

$$
\text { Cycle achievement of teacher action implementation }
$$

Percwentage improvement in achievement of action

\begin{tabular}{lc}
\hline I & $89 \%$ \\
\hline $11 \%$ II & $100 \%$ \\
\hline Source : Data processed 2018
\end{tabular}

Source : Data processed, 2018

Based on the results of preliminary observations conducted by researchers, it is known that the daily test score of many students under the minimum completeness criteria set at SD Labschool UPI is $\geq 75$. Teachers have used learning models of 
discussion, lectures varied, and practice questions. However, student learning outcomes are still not satisfactory and meet the Minimum Criteria of Completeness $(K K M)$ that has been established.

In group discussion activities there are still many students who joked with other group members. iscussion activities only dominated by certain students only so that other students are still less daring to express their opinions. At the end of the first cycle of learning when the teacher gives the test (post-test) many students who are not ready to carry out the test it is seen from the many students who were caught cheating the answer of his friend. To understand the subject matter of economics, students do it by memorizing. How to learn students will affect the learning outcomes to be obtained. Learning outcomes obtained by students are not only influenced by the way students learn, but also influenced by how to teach teachers that can include learning methods, resources and learning media used.

\section{Conclusion}

The result of observation of the implementation in cycle I in good category while the observation result of the implementation of the second cycle on the category is very good. Implementation of Classroom Action Research through lesson study can improve student achievement, this can be seen from the increase of observational student achievement cycle I and cycle II. Classroom Action Research through lessons has been well implemented including the completeness of the learning tools and preparing the Lesson Plans before teaching on each teaching material Based on the results of the implementation of lesson study using the Classroom Action Research can be concluded that the use of lesson study using Classroom Action Research on the learning can improve student achievement.

\section{References}

[1] Asyari, M., Mudhar, M. H. I. A., Susilo, H., \& I. (2015). Improving Critical Thinking Skills through the Integration of Problem-Based Learning and Group Investigation. International Journal for Lesson and Learning Studies, 5 (1), 3644.

[2] Garfield, J. (2006). Exploring the Impact of Lesson Study on Developing Effective Statistics Curriculum. Retrieved from

[3] https://www.stat.auckland.ac.nz/ iase/publications/11/Garfield.doc.

[4] Kemmis, S., \& McTaggart, R. (2007). Action Researh. Communicative Action and the Public

[5] Sphere. In The Sage handbook of qualitative research (pp. 271-330).

[6] Lewis, C. (2002). Lesson study: A handbook of teacher-led instructional change. 130. Saito, E., Hendayana, S., Imansyah, H., Ibrohim, Isamu, K., \& Hideharu, T. (2006).

[7] Development of school-based in-service training under the Indonesian Mathematics and Science Teacher Education Project. Improving Schools, 9(1), 
47-59. https://doi.org/10.1177/1365480206061999

[8] Sudjana. (1996). Metode Statistika. Bandung.

[9] Sukirman D, J. (2006). Perencanaan Pembelajaran.Bandung UPI Press. 